\title{
EMOTIONAL FACE PERCEPTION IN PATIENTS WITH SCHIZOPHRENIA: AN EVENT-RELATED POTENTIAL STUDY
}

\author{
Received December 15, 2012.
}

Emotional face recognition has been shown to be drastically impaired among patients with schizophrenia. Since the underlying processes of this deficit have not been widely addressed, we attempted to investigate the relationship between facial expression perception and clinical symptoms in patients with schizophrenia. We enrolled 28 patients with schizophrenia and 28 healthy adults matched by their sex and age. The amplitude and latency of component N170 in event-related EEG potentials (ERPs) induced by presentations of happy, fearful, and neutral face images were comparatively evaluated in these two groups. Furthermore, the relationship between the N170 measures and clinical symptoms of schizophrenia were assessed using the Positive and Negative Syndrome Scale (PANSS). The N170 responses to facial expressions in patients with schizophrenia were significantly delayed, as compared to healthy control participants $[\mathrm{F}(1,54)=4.25, P=0.044]$. The $\mathrm{N} 170$ response to fearful faces (as compared to happy and neutral faces) was elicited with the minimum latency in the control group, while this component was most delayed among schizophrenics. Positive schizophrenia symptoms correlated with the amplitudes of the left-hemisphere N170 component in response to happy, fearful, and neutral faces. Our findings suggest that the facial expression deficit in schizophrenia is related to delayed responses in face perception and is influenced by the severity of positive symptoms. The evident delay in fearful face perception among patients with schizophrenia may partly explain their inappropriate reactions to threatening conditions.

Keywords: emotional face perception, ERP, N170, schizophrenia, symptom severity.

\section{INTRODUCTION}

Schizophrenia is a severe mental illness encompassing a spectrum of cognitive, social, and emotional impairments [1] and characterized by negative and positive symptoms [2]. Despite compelling evidence on deficient emotional face perception and recognition in patients with schizophrenia, the processes underlying these deficits are still open to debate [3]. Elucidating the possible underlying causes for emotional face processing disorder in schizophrenia would help to suggest effective treatment interventions and remediation strategies. The three main hypotheses

\footnotetext{
${ }^{1}$ Institute for Cognitive Science Studies (ICSS), Tehran, Iran.

${ }^{2}$ School of Rehabilitation, Iran University of Medical Sciences (IUMS), Tehran, Iran.

${ }^{3}$ Department of Psychiatry, Tehran University of Medical Sciences (TUMS), Tehran, Iran.

${ }^{4}$ Department of Biomedical Engineering, Amirkabir University of Technology (AUT), Tehran, Iran.

Correspondence should be addressed to M. Tehrani-Doost

(e-mail: tehranid@tums.ac.ir).
}

of this impairment are the following: (i) cognitive impairment [4], (ii) early-stage visual processing deficits [1], and (iii) general deficit in face or particular emotional face processing $[5,6]$. In terms of general deficiency in facial recognition, some behavioral studies indicated that patients with schizophrenia suffer from an incapability of recognizing face identity (i.e., age, sex, etc.) [7], distinguishing face familiarity $v s$ unfamiliarity [5], and/or providing face detection [8]. A different approach has emphasized the role of emotion-specific disorder in perception and recognition of facial expressions [9]. According to Strauss et al. [10], patients with schizophrenia have difficulties in recognizing emotional faces during labeling or matching tasks for different emotional faces. Schneider et al. [11] reported that schizophrenia patients have a weaker performance in emotional recognition tasks even in easily recognizable emotions, like happiness, without any deficit in age-discrimination tasks, as compared to control subjects [11]. Various neural networks are assumed to be involved during 
processing of distinct facial emotions. For instance, the amygdala has often been linked to fearful and sad face processing, the cingulate sulcus and orbital frontal cortical regions are shown to be activated by viewing of happy and angry faces, respectively, and the basal ganglia and insula are activated in response to disgust faces [12]. Evidence from functional magnetic resonance imaging (fMRI) studies has explained some anatomical underpinnings of the deficits in emotional face processing, such as hypoactivity of the ventral temporal cortex, basal ganglia, and prefrontal cortex [13], as well as hyperactivity of the left hippocampal structures and right amygdala [14] among schizophrenics. In addition, some behavioral studies have substantiated deficits in recognizing negative emotions during emotion identification and discrimination tasks [6], while others emphasized the impairment in recognizing particular emotional faces, such as fearful [15], disgusted [5, 15], angry, and/or sad [16].

Among the variety of methods used in face recognition studies, recording of event-related potentials (ERPs) is one of the most well-established techniques currently applied to investigate the time course of neural responses to different facial expressions. The key component in the face and facial expression studies using ERPs is the N170 deflection [17, 18]. Recent studies demonstrated that patients with schizophrenia exhibit reduced N170 amplitudes during neutral and emotional face processing [19-21]. Campanella et al. [22] demonstrated the absence of "fear N170" modulation in schizophrenia. On the other hand, while Bediou et al. [23] recorded the decreased N170 amplitude in the schizophrenia group during emotional face detection (fear, happiness, disgust, surprise, and neutral), they did not report such a phenomenon during gender detection tasks.

The specific contributions of schizophrenia symptoms to impairment in emotional face processing are still controversial [24]. Some findings indicated that patients with schizophrenia exhibit a cross-link between emotional faces but not age recognition with regard to the severity of negative and positive symptoms of the disease [7]. Meanwhile, some researchers reported associations between positive symptoms, age, and facial emotion recognition [25]. In contrast, van't Wout et al. [26] found that, in the "schizophrenia with fear deficits" group, negative symptoms prevail. In the ERP studies, some authors reported no relationship between the N170 parameters and sub-scales of the Positive and Negative Syndrome
Scale (PANSS) [5, 27, 28], while others suggested a strong association between the N170 indices and negative symptoms using the "Scale for the Assessment of Negative Symptoms" (SANS) global scores [29].

Despite extensive attempts to investigate the impairment of facial expression recognition and perception in schizophrenia, at present there are limited ERP studies explaining the time course of each emotional face perception. Very few such researches examined the relationship between clinical symptoms and facial expression perception. The main goals of our study were: (i) to compare the amplitude and latency of the N170 component between patients with schizophrenia and matched healthy adults while viewing emotional faces, and (ii) to examine the relationship between the amplitude and latency of N170 and the severity of positive and negative symptoms in schizophrenia.

\section{METHODS}

Participants. Thirty patients suffering from schizophrenia (16 man and 14 women) and 34 healthy controls (19 men and 15 women) were enrolled in the study. All control participants and schizophrenics were right-handed (based on the Edinburgh inventory) [30] and matched by age, sex, and their educational levels. Diagnostic criteria for schizophrenia were assessed through a semi-structured diagnostic interview (Schedule for Schizophrenia and Affective Disorder, SADS) [31] administered by a psychiatrist and also through case-file reviews. Patients were confirmed not to have other psychiatric co-morbidities on DSM-IV-TR Axis I. Patients with schizophrenia were recruited from the Roozbeh Psychiatry Hospital, Tehran University of Medical Science (TUMS), Tehran, Iran. Patients were enrolled during their stable chronic phase of schizophrenia. Healthy participants were free from any Axis I or Axis II disorders, history of schizophrenia, or other psychiatric disorders in their first-degree relatives. Across groups, the age varied between 20 to 45 years, and the subjects had $\geq 9$ years of formal education with normal or correctedto-normal visual acuity. Among the exclusion criteria, there were a history of neurological disorders, loss of consciousness due to a head injury, substance dependence or history of substance abuse within the preceding six months, a medical condition that might affect cerebral functioning, and verbal IQ $<75$.

Evaluation of Clinical Symptoms. Evaluation 
of psychopathological symptoms was performed according to the PANSS. This instrument consists of 30 clearly defined items. The PANSS entails three subscales to assess positive (7 items), negative (7 items), and general psychopathological (16 items) symptoms [32].

Task and Original Stimuli. The participants viewed all the stimuli presented on a 17 -inch LG monitor screen, in a dark and quiet room, while they were comfortably seated on a chair with their head positioned and fixed on a chin rest. The distance from the monitor was $60 \mathrm{~cm}$, with an approximately $8 \times 11$ deg visual angle. The experiment included one practice and ten experimental blocks. Each experimental block comprised presentations of five happy, sad, angry, fearful, and neutral face images of Iranian validated peoples. To maintain the vigilance throughout the task, a house image (with a $10 \%$ probability of the total number of stimuli) was used as the target stimulus. The participants were instructed to press on the space bar using their left index finger when responding to the target stimuli.

All face images were in grayscale, oval-trimmed (to remove background, clothing, and hairline), and positioned within a rectangular frame $(261 \times$ 365 pixel array). Each face was repeated 100 times randomly. The pictures were viewed for $500 \mathrm{msec}$ and instantly replaced by a white fixation point in the light gray background $(1024 \times 768$ pixels $)$ during the 1,000 -msec-long interstimulus interval (ISI) with \pm 100 msec randomization. The stimuli were presented at the middle of the monitor screen using Eevoke software. Our aim was to comparatively assess the responses to happy (positive facial expression), fearful (negative facial expression), and neutral faces. This was done through analyzing ERP records in response to the above (happy, fearful, and neutral) facial stimuli.

EEG Recording. Continuous EEG signals were recorded by $32 \mathrm{Ag} / \mathrm{AgCl}$ electrodes mounted in an electrode cap (Waveguard, ANT, Netherlands) according to the international 10-20 standard and additional intermediate positions. Electrooculogram (EOG) electrodes were placed on the outer canthus of each eye, inferior and superior to the left orbit, so as to monitor horizontal and vertical oculomotor artifacts, respectively. Electrode impedances were maintained below $5 \mathrm{k} \Omega$. A 64-channel amplifier (ANT, Netherlands) was used for data recording, and ASA 4.7.1 software was used for data acquisition. The sampling rate was $512 \mathrm{sec}^{-1}$. EEG was recorded online with a $50-\mathrm{Hz}$ notch filter.
ERP Extraction. EEG data were analyzed off-line using ASA 4.7 (ANT, Netherlands), EEGLAB 9.0.8.6.b (a freely available open source toolbox, http:// www. sccn.ucsd.edu/eeglab) and MATLAB 7.10.0 (Math works, USA) software. Raw data were filtered with a band-pass filter of 1 to $80 \mathrm{~Hz}$ and referenced to the mastoids average. Similar to our previous report [33], the eye movement artifacts were canceled using independent component analysis (ICA). A combination of the efficient variant of fast ICA (EFICA) and efficient weight-adjusted SOBI (EWASOBI) was chosen as the ICA method using ICALAB software. In addition, the remaining artifacts with deflection amplitudes of $\pm 100 \mu \mathrm{V}$ from the baseline were eliminated (primarily through automatic artifact reduction by EEGLAB 9.0.8.6.b software and secondarily, through visual inspection made by an expert). Artifact-free EEG recordings were then segmented into epochs ranging from $250 \mathrm{msec}$ pre-stimulus to $1,000 \mathrm{msec}$ poststimulus. Each channel baseline epoch was corrected by prestimulus voltage subtraction.

Feature Extraction. The N170 component of visual ERPs is a negative waveform peaking approximately $155-190$ msec post-stimulus. It is mostly observed in the occipito-temporal sites and, as is commonly supposed, represents the earliest stage of facial structure encoding $[17,19]$. Our detection method for this component was in line with earlier experiments. The maximum-peak amplitude and latency values were automatically extracted from occipito-temporal records (P7, P8) [22, 34] within the time window of 130 to $250 \mathrm{msec}$, and all peaks were confirmed by visual inspection.

Data Processing. Mean values of the amplitude and latency were statistically analyzed using repeatedmeasure analysis of variance (ANOVA) comprising the following core factors: hemisphere (left and right), facial expression (happy, fearful, and neutral), and groups (patients and controls). Greenhouse-Geisser correction was used for the degrees of freedom. In addition, to calculate the direction and magnitude of the association between N170 measures and clinical features, we applied the Spearman's rho nonparametric correlation in SPSS 17.0. Throughout the experiment, differences with $P<0.05$ were considered significant.

\section{RESULTS}

Eight participants were excluded from the study. These included four control subjects due to excessive 
TABLE 1. Characteristics of the Two Studied Groups (Schizophrenia Patients and Control Subjects)

Т а б л и ц я 1. Характеристики двох обстежених груп (пацієнтів із шизофренісю та контрольних суб'сктів)

\begin{tabular}{|c|c|c|c|c|}
\hline Characteristics & $\begin{array}{l}\text { Schizophrenia group } \\
\qquad(n=28)\end{array}$ & $\begin{array}{l}\text { Control group } \\
\quad(n=28)\end{array}$ & \multicolumn{2}{|c|}{ Intergroup difference } \\
\hline Age (years) & $33.32 \pm 5.65$ & $32.61 \pm 6.01$ & 0.45 & 0.65 \\
\hline Illness duration (years) & $11.5 \pm 6.92$ & & & \\
\hline \multicolumn{5}{|l|}{ PANSS scores } \\
\hline General & $42.79 \pm 13.11$ & & & \\
\hline
\end{tabular}

Footnote. Means \pm s.d. values are shown.

$A$
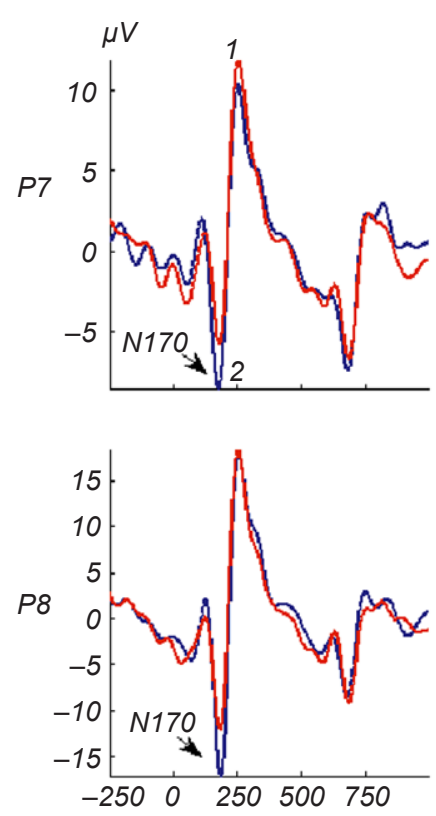

$B$
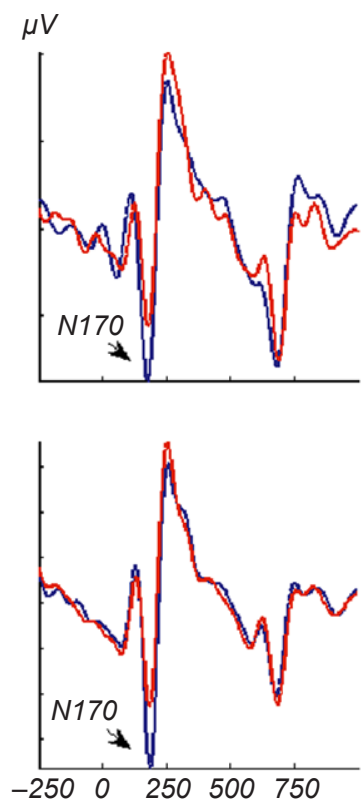

C
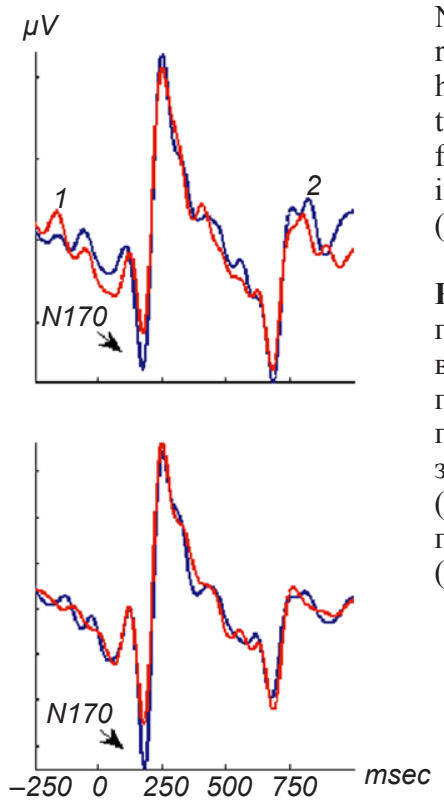

F i g. 1. Grand-average of the N170 components in ERPs recorded from the left and right hemispheres (P7/P8) in response to presentations of happy (A), fearful (B), and neutral (C) face images among the schizophrenia (1) and control (2) groups.

Р и с. 1. Усереднені в межах груп компоненти N170, відведені від лівої та правої півкулі (Р7/P8), в умовах пред'явлення зображень облич зі щасливим $(A)$, переляканим $(B)$ і нейтральним $(C)$ виразом у групі пацієнтів із шизофренією (1) та в контрольній групі (2). rejected trials, two patients due to inaccuracies in the PANSS scores, and finally two other control subjects in order to better maintain group matching by age and sex. Altogether, 28 patients (16 men and 12 women) and 28 control subjects ( 16 men and 12 women) were included in the study (details are summarized in Table 1).

The mean and s.e.m. values for the N170 amplitude and latency in response to different facial expressions are shown in Table 2. The grand averages of the N170 waveforms across the three types of facial expressions (P7/P8) are illustrated in Fig. 1.

Repeated-measure ANOVA demonstrated a significant main effect of the hemisphere $(\mathrm{F}[1,54]=$ $=40.83, P=0.001)$ and the interaction effect of hemisphere $\times$ facial expression $(\mathrm{F}[2,108]=5.43, P=$ $=0.006)$ on the N170 amplitude. Pairwise comparisons revealed larger N170 peaks throughout the right hemisphere in both groups. No significant main effects of facial expression and interaction effects of facial expression $\times$ group, as well as hemisphere $\times$ group on the N170 amplitude, were documented. Moreover, the two groups showed no significant difference in terms of the N170 amplitude.

With regards to the N170 latency, repeatedmeasure ANOVA revealed a significant main effect of the group $(\mathrm{F}[1,54]=4.25, P=0.044)$. The result of pairwise comparison indicated that the N170 latency tended to be shorter in the left hemisphere. Moreover, for schizophrenics, further analysis of 
TABLE 2. Parameters of Component N170 in Event-Related EEG Potentials Evoked in Response to Presentation of Images of Facial Expression

T а б л и ц я 2. Параметри компонента N170 у складі пов'язаних 3 подісю потенціалів, котрі були викликані пред'явленням зображень облич з різними виразами

\begin{tabular}{cl|c|c|c|c}
\hline \multirow{2}{*}{ Parameters } & \multirow{2}{*}{ Facial expression } & \multicolumn{2}{|c|}{ Left hemisphere } & \multicolumn{2}{c}{ Right hemisphere } \\
\cline { 3 - 6 } & & schizophrenia group & control group & schizophrenia group & control group \\
\hline \multirow{2}{*}{ Amplitude, $\mathrm{mV}$} & fearful & $-11.94 \pm 2.15$ & $-13.57 \pm 1.55$ & $-16.62 \pm 2.45$ & $-21.88 \pm 2.6$ \\
& happy & $-10.93 \pm 2.04$ & $-11.74 \pm 1.62$ & $-18.02 \pm 2.08$ & $-21.79 \pm 2.7$ \\
& neutral & $-11.14 \pm 1.9$ & $-10.89 \pm 1.99$ & $-18.18 \pm 2.55$ & $-22.39 \pm 2.6$ \\
& fearful & $192.72 \pm 5.33$ & $170.93 \pm 4.2$ & $183.03 \pm 3.74$ & $176.38 \pm 3.70$ \\
Lattency, msec & happy & $186.5 \pm 4.11$ & $176.27 \pm 4.3$ & $180.10 \pm 2.08$ & $182.66 \pm 3.91$ \\
& neutral & $186.44 \pm 4.94$ & $177.24 \pm 4.09$ & $183.24 \pm 3.25$ & $179.96 \pm 3.48$ \\
\hline
\end{tabular}

Footnote. Means \pm s.e.m. are shown.

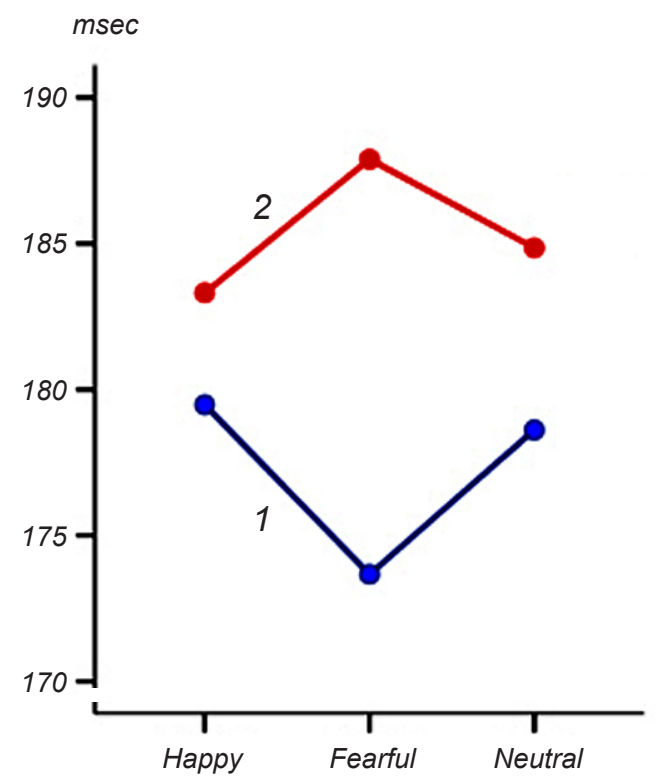

F i g. 2. Dependence of the mean values of the N170 latency, msec, on the facial expression in the presented images; 1 and 2) control group and patients with schizophrenia, respectively.

P и с. 2. Залежність середніх величин латентного періоду (мс) компонента N170 від виразу обличчя на пред'явлених зображеннях у контрольній групі (1) та групі пацієнтів із шизофренією (2).

hemisphere $\times$ group $(\mathrm{F}[1,54]=4.64, P=0.036)$ interaction suggested that, although the N170 response to different facial expressions in this group is delayed in both hemispheres (as compared to the controls), this disparity between the two groups is particularly significant in the left hemisphere (hemispheres: left, $t=-2.58, P=0.013 v s$ right, $t=-0.60, P=0.545)$.

Repeated-measure ANOVA indicated the significant interaction effect of facial expression $\times$ group
$($ F $[2,108]=3.57, P=0.039)$ on the N170 latency. Despite the different intergroup trend of the N170 latency in response to different facial expressions (Fig. 2) in terms of the time course and priority, separate post-hoc analysis between different facial expressions in each group showed no significant difference for the N170 latency in response to faces in both groups. Nevertheless, the N170 latency in response to fearful faces was the only significantly differing measure between the two groups $(t=2.95$, $P=0.005$ ).

No relationships were found between the N170 amplitude/latency and negative/general psychopathology symptoms in the schizophrenia group. However, the positive symptoms demonstrated a significant correlation with the "left" amplitude of N170, as are shown boldfaced in Table 3.

\section{DISCUSSION}

The aims of our study were, firstly, to compare the ERP features of the N170 component among patients with schizophrenia and healthy controls when passively viewing the posed happy, fearful, and neutral face images and, secondly, to investigate the relationship between the N170 characteristics and clinical symptoms (using PANSS) of schizophrenia. The study yielded three main results. First, in terms of comparing the N170 between the two groups, patients with schizophrenia exhibited longer latencies and smaller N170 peaks in response to happy, fearful, and neutral faces regardless of their expressions than those in the control group. Moreover, the only significant difference between the two groups was the disparity in the N170 latency. What is inferred from this finding is 
TABLE 3. Correlations between the Amplitude and Latency of Component N170 and Clinical Symptoms in the Schizophrenia Group $(n=28)$

T а б л и ц я 3. Кореляція між величинами амплітуди й латентного періоду компонента N170 і виразністю клінічних симптомів у групі пацієнтів із шизофренією $(n=28)$

\begin{tabular}{|c|c|c|c|c|}
\hline \multirow[t]{2}{*}{ N170 parameter/hemisphere } & Facial expressions & Positive symptoms & $\begin{array}{l}\text { Negative } \\
\text { symptoms }\end{array}$ & $\begin{array}{c}\text { General psychopathology } \\
\text { symptoms }\end{array}$ \\
\hline & & \multicolumn{3}{|c|}{ rho } \\
\hline \multirow[t]{2}{*}{ Amplitude / Left } & fearful & $-0.57 * *$ & 0.18 & -0.02 \\
\hline & neutral & $-0.48 * *$ & 0.13 & -0.05 \\
\hline Latency / Left & fearful & $-0.39 *$ & -0.15 & -0.15 \\
\hline \multirow[t]{3}{*}{ Amplitude / Right } & fearful & -0.14 & 0.005 & 0.005 \\
\hline & happy & 0.02 & 0.1 & 0.1 \\
\hline & neutral & -0.26 & 0.02 & 0.02 \\
\hline \multirow[t]{2}{*}{ Latency / Right } & fearful & 0.08 & -0.08 & -0.08 \\
\hline & happy & -0.05 & -0.15 & -0.15 \\
\hline
\end{tabular}

Footnotes. rho) Spearman's rank correlation coefficient. One and two asterisks show cases of significant correlations with $P<0.05$ and $<0.04$, respectively. Positive symptoms demonstrating a significant correlation with the "left" amplitude and latency of component N170 are shown boldfaced.

that, regardless of the particular expression, faces are processed in almost the same way in the schizophrenia group as in the control group; however, the perception process is carried out later. This delay in the early stage of perception may possibly lead to face recognition deficits among patients with schizophrenia. To arrive at a more solid conclusion with this respect, other emotional faces and their related elicited components should be investigated. This finding is consistent with other reports in terms of N170 deficiencies in schizophrenia. According to Campanella et al. [22], subjects with schizophrenia tend to exhibit smaller amplitudes of P100 and N170 with delayed latencies when assigned to the emotional face oddball task (neutral faces as frequent stimuli, and sad, fearful, or happy faces as target stimuli). This has been linked to deficiencies in the early stage of face perception among these patients. Turetsky et al. [21] reported significant group differences for the N170 component features, which were sensitive to face structural encoding but not to the affect modulation of the N250 component. The authors concluded that emotional face recognition deficits are potentially due to faulty structural encoding of faces in the patient group [21]. Along with these lines, Caharel et al. [5] reported the smaller amplitudes and longer latencies of P1 and N170 in response to facial expressions (disgust, happy, and neutral) and familiarity tasks. They proposed that this deficit was possibly due to a generalized dysfunction at sensory (P1) and perceptual (N170) stages of face processing. Based on some other reports, when patients with schizophrenia passively attend to emotional faces, their N170 a features represent characteristically a similar pattern. Lower amplitudes and prolonged latencies of the N170 component, as compared to those in normal subjects, were shown. However, the extent of these dissimilarities varied in different studies [19, 27]. The findings vary among different investigations, including ours. The inconsistency in the amplitude of N170 in various reports may be due to the type of the task [22] or of emotional faces [5, 21], and differences in the signal analysis method (mean global field power, while we examined the mean amplitude) $[5,27]$.

In contrast, several authors have reported the N170 components of almost the same features in response to facial expressions in both groups. Wynn et al. [35] proposed similar trends of P100 and N170 in the schizophrenia and control groups in response to fearful, angry, ashamed, happy, sad, and surprised faces. However, they found a significant difference in N250 (in response to emotional faces) between the two groups. The inconsistency seen between the above data and that of ours may at least partly be due to the difference in time windows for N170 examination (140-220 
msec in other studies $v s$ 130-250 msec in the current investigation).

Second, our findings have demonstrated significantly different trends for the N170 latency in response to fearful, happy, and neutral faces between the two groups. In our control group, regardless of the hemisphere effect of facial expressions, the fastest N170 response was evoked to presentation of fearful faces (followed by happy and neutral faces). Conversely, responses to fearful faces were the slowest in the schizophrenia group, as compared to other facial expressions (Fig. 2). Given the above, the emotional face perception in schizophrenia patients compared to controls turned out to be not only more delayed but also having different characteristic features. As expected, the fearful expression (as a threatening stimulus), which requires a faster response to danger, fear, and misery, was related to the shortest-latency N170 in the normal group. In contrast, the schizophrenia group failed to show such sensitivity to fearful stimuli. The above finding is in line with those of Campanella et al. [22], Lee et al. [27], and Kirihara et al. [36]. As was indicated in some studies, the difference in emotional face responses between the two groups is seen in the subsequent components, mainly the N250 [35]. According to Herrmann et al. and An et al. [28, 37], the emotional face perception deficits in schizophrenia is predominantly due to the failure in the decoding phase and a decrease in the positive amplitudes at $300 \mathrm{msec}$ over the parietal brain areas. We have not studied other ERP components; however, we can expect that this disparity in early-stage face processing can potentially affect the subsequent components, such as N250 or P300.

On the other hand, according to the study of Gur et al. [38], the performance of schizophrenia-group patients with the flat affect was poorer than that in the healthy group, and this impairment corelated exclusively with positive clinical symptoms. Although the methodology and task type of the above study is entirely different from those in our work, we may atribute link longer latencies of N170 (modulated by positive symptoms) to a blunted affect seen in schizophrenia.

Third, considering our own results, the amplitude of the left N170 in response to happy, fearful, and neutral faces and also the latency of the left N170 in response to fearful faces are modulated by positive symptoms in patients with schizophrenia. In other words, regardless of the type of facial expressions, a greater severity of positive symptoms induces more engagement of the neural processors during the face encoding (the absolute value of the N170 amplitude). The relationship between positive symptoms and the amplitude of N170 is consistent with Campanella et al. [22] and Turetsky et al. [21]; however, they found this relationship with bilateral N170s. As opposed to Thoma et al. [39] who found that the negative symptoms in patients with schizophrenia correlated with the dysfunction of right-hemisphere and sensory gating impairments, Higashima et al. [40] demonstrated an association between the left posterior temporal region with positive symptoms presentations, such as delusions and thought disorders [40]. As expected, the correlation between abnormal activation of the left medial and lateral temporal regions with positive symptoms may be one reason for the modulation of the left N170 amplitude in response to facial expression.

From a neuroimaging point of view, results of an fMRI study in schizophrenia have demonstrated the relationship between clinical symptoms and impairments of some particular brain regions that are typically involved during emotional tasks. Since the correlation between positive symptoms and the activity of the amygdala, hippocampal/parahippocampal structures, and medial prefrontal cortex has been established [2], it may be concluded that the impairment of some key regions, such as amygdala (which plays an important role in detection of emotional and, especially, fearful faces) is influenced by positive symptoms. Moreover, the severity of positive symptoms may influence compensatory mechanisms in brain circuits [41]. The need to further explanation of these possible mechanisms makes additional basic and complex facial expression studies worthwhile.

Finally, the main limitations of our study should be noted. Firstly, all participants in the patient group were on medication that could not be changed because of ethical reasons. So, we did not examine the effect of medicine on the N170 component that can be influenced by some types of drugs. Secondly, we did not compare the facial perception in different types of schizophrenia, and this was due to the limited sample size.

To conclude, the impairment of "facial expression" perception in schizophrenia is potentially linked to delays in face perception per se, regardless of the expressions. Interestingly, the amplitude of the lefthemisphere N170 in response to happy, fearful, and neutral faces and the latency of the N170 evoked by fearful faces were influenced by the severity of positive symptoms in schizophrenia. The delay in 
perception of fearful faces in schizophrenia can be considered as one of the many reasons explaining inappropriate reactions of these patients to threatening conditions.

The ethical protocol of this study was based on the Helsinki Declaration, and written informed consent signed by all participants prior to their enrollment was obtained.

Acknowledgment. This study was a part of the first author's thesis to obtain the PhD degree in cognitive neuroscience (brain and cognition) at the Institute for Cognitive Science Studies, Tehran, Iran.

\section{М. Акбарфахімі ${ }^{1,2}$, M. Техрані-Доост ${ }^{3,1}$, Ф. Гассемі ${ }^{4,1}$}

\section{СПРИЙНЯТТЯ ЕМОЦІЙНОГО ВИРАЗУ ОБЛИЧЧЯ У ПАЦІЕНТІВ, КОТРІ СТРАЖДАЮТЬ НА ШИЗОФРЕНІЮ: ДОСЛІДЖЕННЯ З ВІДВЕДЕННЯМ ПОВ'ЯЗАНИХ 3 ПОДІЕЮ ЕЕГ-ПОТЕНЦІАЛІВ}

${ }^{1}$ Інститут 3 дослідження когнітивних функцій (ICSS), Тегеран (Іран).

${ }^{2}$ Інститут реабілітації, Ірінський медичний університет, Тегеран (Іран).

3 Тегеранський медичний університет, Тегеран (Іран).

${ }^{4}$ Технологічний університет, Аміркабір (AII), Тегеран (Іран).

P е 3 ю м е

У пацієнтів, котрі страждають на шизофренію, розпізнавання виразів обличчя $є$ серйозно порушеним. Оскільки процеси, що зумовлюють подібний дефіцит, вивчені недостатньо, ми намагалися дослідити співвідношення сприйняття виразів обличчя та клінічних симптомів у пацієнтів із цим захворюванням. В обстежувану групу ввійшли 28 пацієнтів із діагнозом шизофренія та 28 дорослих суб'єктів; групи були узгоджені в статевому та віковому аспектах. У представників цих двох груп вимірювали та порівнювали амплітуду й латентний період компонента N170 у складі пов'язаних 3 подією потенціалів, викликаних пред'явленням зображень облич зі щасливим, переляканим і нейтральним виразом. Потім оцінювали взаємозв'язок параметрів N170 з оцінками клінічних симптомів шизофренії згідно зі шкалою позитивних і негативних синдромів (PANSS). Розвиток компонента N170 після пред'явлення зображень облич з різними виразами відбувався у пацієнтів із шизофренією істотно пізніше, ніж у здорових контрольних суб'єктів $[\mathrm{F}(1,54)=$ $=4.25, P=0.044]$. N170 після пред'явлення переляканих облич (порівняно зі щасливими та нейтральними) розвивався у суб' єктів контрольної групи з мінімальною затримкою, а у шизофреників він виникав значно пізніше. Інтенсивність позитивних симптомів у шизофреників корелювала 3 амплітудами N170 у лівій півкулі після пред'явлення як щасливих, так і переляканих і нейтральних облич. Наші спо- стереження показують, що дефектність сприйняття виразу обличчя у пацієнтів, хворих на шизофренію, пов'язана із затримкою відповідей ЦНС, і на таку дефектність впливає тяжкість позитивних симптомів. Очевидна затримка сприйняття облич 3 переляканим виразом у пацієнтів із шизофренією може частково пояснювати неадекватність їх реакцій на загрозливі ситуації.

\section{REFERENCES}

1. A. Martinez, S. A. Hillyard, E. C. Dias, et al., "Magnocellular pathway impairment in schizophrenia: evidence from functional magnetic resonance imaging," J. Neurosci., 28, 7492-7500 (2008).

2. V. M. Goghari, S. R. Sponheim, and A. W. MacDonald, "The functional neuroanatomy of symptom dimensions in schizophrenia: a qualitative and quantitative review of a persistent question," Neurosci. Biobehav. Rev., 34, 468-486 (2010)

3. C. G. Kohler, J. B. Walker, E. A. Martin, et al., "Facial emotion perception in schizophrenia: a meta-analytic review," Schizophr. Bull., 36, 1009-1019 (2010).

4. G. Sachs, D. Steger-Wuchse, I. Kryspin-Exner, et al., "Facial recognition deficits and cognition in schizophrenia," Schizophr. Res., 68, 27-35 (2004).

5. S. Caharel, C. Bernard, F. Thibaut, et al., "The effects of familiarity and emotional expression on face processing examined by ERPs in patients with schizophrenia," Schizophr. Res., 95, 186-196 (2007).

6. J. Huang, T. Xu, and R. C. Chan, "Do patients with schizophrenia have a general or specific deficit in the perception of social threat? A meta-analytic study," Psychiat. Res., 185, 1-8 (2011).

7. C. G. Kohler, W. Bilker, M. Hagendoorn, et al., "Emotion recognition deficit in schizophrenia: association with symptomatology and cognition," Biol. Psychiat., 48, 127-136 (2000).

8. Y. Chen, D. Norton, R. McBain, et al., "Visual and cognitive processing of face information in schizophrenia: detection, discrimination and working memory," Schizophr. Res., 107, 92-98 (2009).

9. R. C. Chan, H. Li, E. F. Cheung, et al., "Impaired facial emotion perception in schizophrenia: a meta-analysis," Psychiat. Res., 178, 381-390 (2010).

10. G. P. Strauss, S. S. Jetha, S. A. Ross, et al., "Impaired facial affect labeling and discrimination in patients with deficit syndrome schizophrenia," Schizophr. Res., 118, 146-153 (2010).

11. F. Schneider, R. C. Gur, K. Koch, et al., "Impairment in the specificity of emotion processing in schizophrenia," Am. J. Psychiat., 163, 442-447 (2006).

12. M. Batty and M. J. Taylor, "Early processing of the six basic facial emotional expressions," Brain Res. Cogn. Brain Res., 17, 613-620 (2003).

13. H. Li, R. C. Chan, G. M. McAlonan, et al., "Facial emotion processing in schizophrenia: a meta-analysis of functional neuroimaging data," Schizophr. Bull., 36, 1029-1039 (2010).

14. D. J. Holt, L. Kunkel, A. P. Weiss, et al., "Increased medial temporal lobe activation during the passive viewing of emotional and neutral facial expressions in schizophrenia," 
Schizophr. Res., 82, 153-162 (2006).

15. Y. J. Pan, S. H. Chen, W. J. Chen, et al., "Affect recognition as an independent social function determinant in schizophrenia," Comp. Psychiat., 50, 443-452 (2009).

16. B. Bediou, N. Franck, M. Saoud, et al., "Effects of emotion and identity on facial affect processing in schizophrenia," Psychiat. Res., 133, 149-157 (2005).

17. A. A. Kovalenko and V. B. Pavlenko, "Emotional significance of the stimulus and features of the personality as factors reflected in the pattern of evoked EEG potentials," Neurophysiology, 41, No. 4, 282-302 (2009).

18. T. Nakashima, K. Kaneko, Y. Goto, et al., "Early ERP components differentially extract facial features: evidence for spatial frequency-and-contrast detectors," Neurosci. Res., 62, 225-235 (2008).

19. M. J. Herrmann, H. Ellgring, A. J. Fallgatter, et al., "Early-stage face processing dysfunction in patients with schizophrenia," Am. J. Psychiat., 161, 915-917 (2004).

20. P. J. Johnston, W. Stojanov, H. Devir, et al., "Functional MRI of facial emotion recognition deficits in schizophrenia and their electrophysiological correlates," Eur. J. Neurosci., 22, 1221-1232 (2005).

21. B. I. Turetsky, C. G. Kohler, T. Indersmitten, et al., "Facial emotion recognition in schizophrenia: when and why does it go awry?" Schizophr. Res., 94, 253-263 (2007).

22. S. Campanella, C. Montedoro, E. Streel, et al., "Early visual components (P100, N170) are disrupted in chronic schizophrenic patients: an event-related potentials study," Neurophysiol. Clin., 36, 71-78 ( 2006).

23. B. Bediou, M. A. Henaff, O. Bertrand, et al., "Impaired fronto-temporal processing of emotion in schizophrenia," Neurophysiol. Clin., 37, 77-87 (2007).

24. G. D. Pearlson, "Neurobiology of schizophrenia," Ann. Neurol., 48, 556-566 (2000).

25. P. Rocca, F. Castagna, T. Mongini, et al., "Exploring the role of face processing in facial emotion recognition in schizophrenia," Acta Neuropsychiat., 21, 292-300 (2009).

26. M. van 't Wout, A. Aleman, R. P. C. Kessels, et al., "Exploring the nature of facial affect processing deficits in schizophrenia," Psychiat. Res., 150, 227-235 (2007).

27. S. H. Lee, E. Y. Kim, S. Kim, et al., "Event-related potential patterns and gender effects underlying facial affect processing in schizophrenia patients," Neurosci. Res., 67, 172-180 (2010).

28. M. J. Herrmann, A. Reif, B. E. Jabs, et al., "Facial affect decoding in schizophrenic disorders: a study using eventrelated potentials," Psychiat. Res., 141, 247-252 (2006).

29. M. Streit, A. Ioannides, T. Sinneman, et al., "Disturbed facial affect recognition in patients with schizophrenia associated with hypoactivity in distributed brain regions: a magnetoencephalographic study," Am. J. Psychiat., 158, 14291436 (2001).
30. R. C. Oldfield, "The assessment and analysis of handedness: the Edinburgh inventory," Neuropsychologia, 9, 97-113 (1971).

31. J. Endicott and R. L. Spitzer, "A diagnostic interview: the schedule for affective disorders and schizophrenia," Arch. Gen. Psychiat., 35, 837-844 (1978).

32. S. R. Kay, L. A. Opler, and J. P. Lindenmayer, "The positive and negative syndrome scale (PANSS): rationale and standardization," Br. J. Psychiat., Suppl., 59-67 (1989).

33. F. Ghassemi, M. H. Moradi, M. Tehrani-Doost, et al., "Effects of correct and wrong answers on ERPs recorded under conditions of the continuous performance test in ADHD/ normal participants," Neurophysiology, 42, No. 3, 213-220 (2010).

34. M. Eimer, "The face-specific N170 component reflects late stages in the structural encoding of faces," Cogn. Neurosci., 11, 2319-2324 (2000).

35. J. K. Wynn, J. Lee, W. P Horan, et al., "Using event related potentials to explore stages of facial affect recognition deficits in schizophrenia," Schizophr. Bull., 34, 679-687 (2008).

36. K. Kirihara, K. Kasai, M. Tada, et al., "Neurophysiological impairment in emotional face processing is associated with low extraversion in schizophrenia," Prog. Neuropsychopharmacol. Biol. Psychiat., 37, 270-275 (2012).

37. S. K. An, S. J. Lee, C. H. Lee, et al., "Reduced P3 amplitudes by negative facial emotional photographs in schizophrenia," Schizophr. Res., 64, 125-135 (2003).

38. R. E. Gur, C. G. Kohler, J. D. Ragland, et al., "Flat affect in schizophrenia: relation to emotion processing and neurocognitive measures," Schizophr. Bull., 32, 279-287 (2006).

39. R. J. Thoma, F. M. Hanlon, S. N. Moses, et al., "M50 sensory gating predicts negative symptoms in schizophrenia," Schizophr. Res., 73, 311-318 (2005).

40. M. Higashima, T. Nagasawa, Y. Kawasaki, et al., "Auditory P300 amplitude as a state marker for positive symptoms in schizophrenia: cross-sectional and retrospective longitudinal studies," Schizophr. Res., 59, 147-157 (2003).

41. J. Hall, J. M. Harris, R. Sprengelmeyer, et al., "Social cognition and face processing in schizophrenia," Br. J. Psychiat., 185, 169-170 (2004). 